\title{
EXPLORATION FOR WILD Helianthus SPECIES FROM THE DESERT SOUTHWESTERN USA FOR POTENTIAL DROUGHT TOLERANCE
}

\author{
Seiler, G.J. ${ }^{1 *}$, Gulya, T.J. ${ }^{1}$ and Fredrick Marek, L. ${ }^{2}$ \\ ${ }^{1}$ U.S. Department of Agriculture, Agricultural Research Service, Northern Crop \\ Science Laboratory, $130718^{\text {th }}$ St. N., Fargo, North Dakota, 58105 USA \\ ${ }^{2}$ USDA-ARS, North Central Regional Plant Introduction Station, Iowa State Uni- \\ versity, Ames, Iowa, 50011 USA
}

Received: October 15, 2006 Accepted: December 05, 2006

\section{SUMMARY}

The ability of some sunflower species to survive and thrive in shifting sand dunes with an annual precipitation of $50 \mathrm{~mm}$ could be of value for cultivated sunflower, a crop often grown in arid regions. The genus Helianthus comprises 51 species and 19 subspecies, with 14 annual and 37 perennial species, all native to North America. The objective of this study was to collect achenes from as many populations as possible of desert species, specifically annual $H$. anomalus, $H$. deserticola, $H$. niveus ssp. canescens, and perennial $H$. niveus ssp. tephrodes from the desert southwestern USA and make them available for future research and improvement of cultivated sunflower. The first exploration for $H$. anomalus and $H$. deserticola took place from September 16 to 23, 2000, covering $4100 \mathrm{~km}$ in three states, Utah, Arizona, and Nevada; while the second exploration concentrated on $H$. deserticola populations in west central Nevada, taking place between June 20 to 23 and August 15 to 18,2005 . The third exploration for $H$. niveus ssp. tephrodes took place from February 26 through March 5, 2005, covering $2200 \mathrm{~km}$ in southern California and adjacent Arizona. Only one population of $H$. deserticola from Utah and two populations of $H$. anomalus from Utah were collected in 2000. The 2005 exploration in Nevada resulted in the collection of achenes from $13 \mathrm{popu}$ lations of $H$. deserticola. In 2005, five populations of $H$. niveus ssp. tephrodes were collected from the Alogodones Dunes in California. One population of $H$. niveus ssp. canescens was collected from Yuma, Arizona, near the US-Mexico border, with three additional populations collected from the Pinta Sands area of Arizona, which is the northernmost extension of the Gran Desierto of Sonora, Mexico. Achene samples of each collection are maintained and distributed from the USDA-ARS National Plant Germplasm System, North Central Regional Plant Introduction Station, Ames, Iowa. The limited number of desert species populations collected will provide basic germplasm for further research dealing with improving drought tolerance in cultivated sunflower.

* Corresponding author: Phone: +1 701239 1380, Fax: +1 701239 1346,

e-mail: seilerg@fargo.ars.usda.gov 


\section{Key words: sunflower, wild species, germplasm, exploration,} drought tolerance

\section{INTRODUCTION}

In natural ecosystems, the ability of plants to survive environmental stress is probably more important than high achene productivity. During the process of selecting plants for high achene yield, sunflower breeders may have inadvertently lost some drought survival mechanisms common in wild sunflower species; therefore, cultivated sunflower could potentially benefit from an infusion of traits from the wild species that would enhance drought tolerance. The wild progenitors of the crop species could be potential sources for enhancing the root system of cultivated sunflower.

Helianthus anomalus Blake is a rare endemic species adapted to sand dune and swale habitats in Utah and northern Arizona (Heiser, 1958; Heiser et al., 1969; Thompson et al., 1981; Nabhan and Reichhardt, 1983). Helianthus deserticola Heiser is a xerophytic annual species found in sandy soils on the floor of the Great Basin Desert in small populations in western Nevada, west central Utah, and along the border of Utah and Arizona (Heiser et al., 1969; Seiler and Cuk, 1981).

Helianthus niveus (Benth.) Brandegee contains three subspecies, all of which grow in xeric sandy soil and sand dunes (Heiser et al., 1969). Only annual $H$. niveus ssp. canescens and perennial $H$. niveus ssp. tephrodes were collected. The third subspecies, Helianthus niveus (Benth.) Brandegee ssp. niveus, a perennial species occurring on the west coast of Baja California from Sensal to Santa Margarita Island where it is found in disturbed sites on sand dunes, was not collected because it was outside of the range of the desert southwest USA.

Helianthus niveus (Benth.) Brandegee ssp. tephrodes (A. Gray) Heiser is a perennial species found in the Gran Desierto, Sonora, Mexico, and in the Algodones Dunes, Imperial County, California. Helianthus niveus (Benth.) Brandegee ssp. canescens (A. Gray) Heiser is an annual or rarely perennial sunflower species in sandy soils of southeastern New Mexico and western Texas, west to southern California and northern Mexico.

These wild sunflower species are a potential source of genes for improving cultivated sunflower. They are excellent candidates for drought tolerance due to their desert adaptability. However, the utility of a germplasm collection is enhanced when there is considerable genetic diversity within species; i.e., more accessions per species are available for research. Due to the demand for achenes of these species (except for $H$. niveus ssp. canescens), and the difficulties in regenerating the populations collected over 20 years ago, achenes of many of the desert sunflowers have not been available for research for almost 20 years. The objective of these explorations was to collect achenes from as many populations as possible of annual $H$. anomalus, $H$. deserticola, $H$. niveus ssp. canescens, and perennial $H$. niveus ssp. 
tephrodes from the desert southwestern USA, and make them available for research and improvement of cultivated sunflower.

\section{MATERIALS AND METHODS}

The exploration for $H$. anomalus and $H$. deserticola took place between 16 and 23 September, 2000. It covered a distance of $4100 \mathrm{~km}$ in three states: Utah, Arizona, and Nevada. Heads were collected from 200 to 250 plants within each population and bulked into a single sample.

The exploration for $H$. deserticola in 2005 was undertaken in two parts, from June 20 to 23, and from August 15 to 18, concentrating solely in Churchill County, west central Nevada. Heads were collected from 200 to 1000 plants within each population and bulked into a single sample.

The exploration for $H$. niveus subspecies took place from February 26 through March 5, 2005, covering $2150 \mathrm{~km}$ in southern California and adjacent Arizona. Seventy-five to 900 heads were collected from 200 to 250 plants within each population and bulked into a single sample.

Herbarium specimens were deposited at the USDA-ARS wild Helianthus herbarium at Fargo, North Dakota. Achene samples were sent to the USDA-Agricultural Research Service, North Central Regional Plant Introduction Station, Ames, Iowa, where they will be maintained and distributed.

All populations were collected within the broad distributional range of the species and subspecies. Specific site information obtained from local botanists, generalized distribution maps, and federal and state agencies was used to locate populations. Population size (number and extent), habitat, soil type, soil sample, achene set per head, the presence of diseases and insects, photo documentation, and other wild sunflower species near the collection sites were recorded for each population. Location of each population was recorded using a global positioning system (GPS) to obtain specific coordinates. Elevation was also recorded at each location.

\section{RESULTS AND DISCUSSION}

Two species, $H$. deserticola and $H$. anomalus, were collected during the 2000 exploration. It had been 20 years since known populations of these two species were last visited. For unexplained reasons, only one population of $H$. deserticola and two of $H$. anomalus had achene-bearing plants in 2000. It had been extremely dry in most of the areas explored with no evidence of the species being present in the most of the fragile sandy habitats. In contrast, the 2005 exploration to west central Nevada for $H$. deserticola was quite successful collecting achenes from 13 populations, in part due to adequate rainfall, and also due to population monitoring by the U. S. Department of the Interior, Bureau of Land Management, and the Nevada Natural Heritage Program (Nevada Natural Heritage Program, 2001). Populations of 
H. deserticola in Churchill County, Nevada produced on average 11 achenes per head. Owing to the large populations, we were able to collect an average of 5000 achenes per population.

Helianthus anomalus is a diploid annual species of hybrid origin that is endemic to active sand dunes, an extreme environment compared with the habitat of its parents, H. annuus L. and H. petiolaris Nutt. (Ludwig et al., 2004) (Figure 1). Based on the occurrence of $H$. anomalus in sand dune desert habitats, it frequently has been recognized as drought tolerant with high oil concentration potential, and thus is a candidate for improving cultivated sunflower germplasm (Nabhan and Reichhardt, 1983; Seiler, 1992).

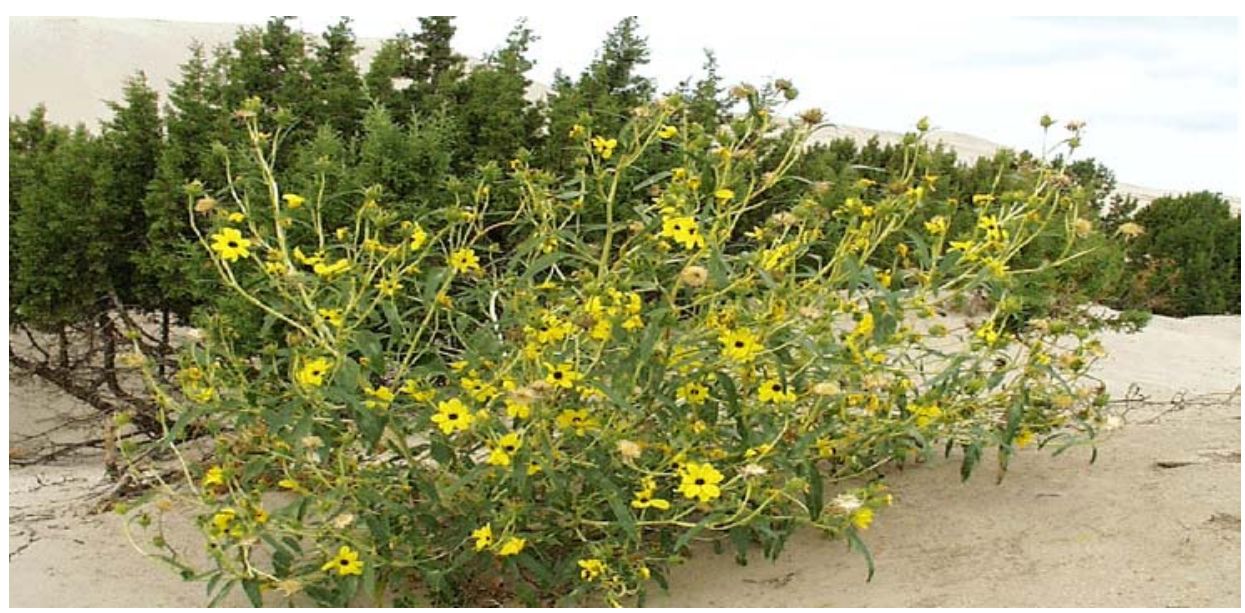

Figure 1: Helianthus anomalus, Jaub Co., Utah. Note white shifting sand dunes and cedars in the background.

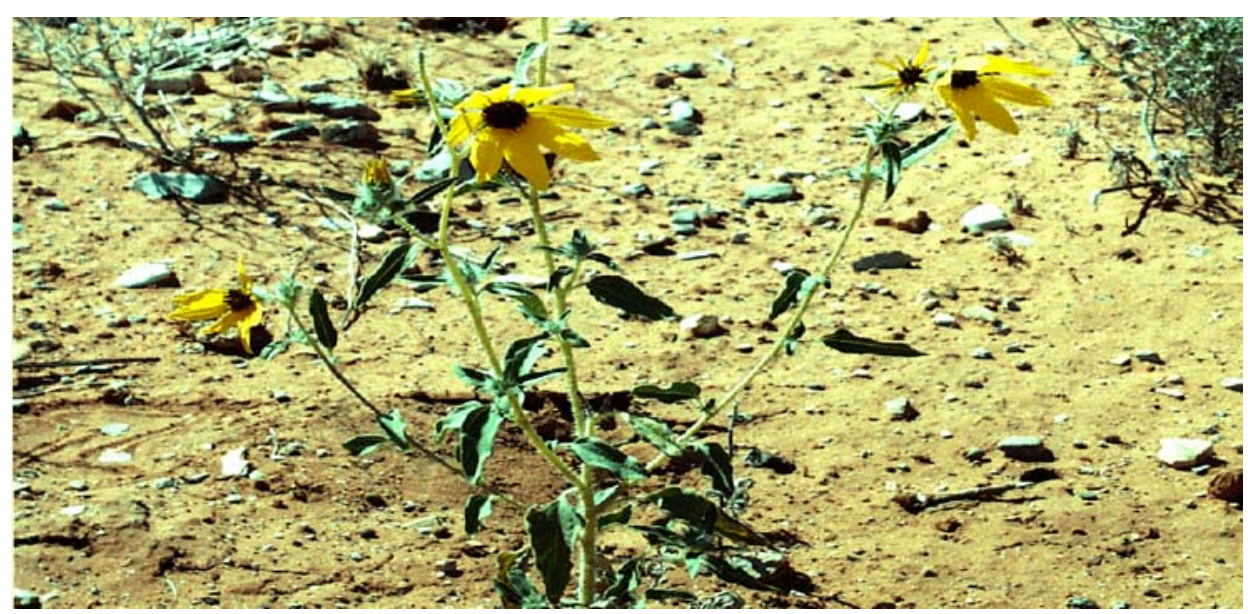

Figure 2: Helianthus deserticola, Washington Co., Utah. Typical plant with branching below and terminal heads. Annual H. deserticola in Churchill Co., Nevada generally had only one to two heads per plant. 
Helianthus deserticola is also a diploid hybrid that inhabits the desert floor, an extreme environment relative to that of its parental species, $H$. annuus and $H$. petiolaris (Gross et al., 2004) (Figure 2). Based on its occurrence on the sandy desert floor, it frequently has been recognized as drought tolerant, and thus is a candidate for improving cultivated sunflower germplasm (Seiler, 1992).

The seven-day exploration trip in 2005 through southern California and adjacent Arizona for $H$. niveus subspecies resulted in the collection of achenes from nine populations. Unusually high fall and winter rainfalls, in some areas up to five times average precipitation, produced a desert flora not observed for many years (Bowers, 2005), affording us the rare opportunity to collect these desert sunflowers. Prior to the current exploration, 12 accessions of $H$. niveus ssp. canescens were available for distribution and research from the USDA Helianthus germplasm collection located at Ames, Iowa. One accession of H. niveus ssp. tephrodes was previously available for distribution.

Five populations of $H$. niveus ssp. tephrodes were collected from the Alogodones Dunes in California (Figure 3). The five populations represented the northern and southern extremes of the 64-km-long dune system. The flowering heads of $H$. niveus ssp. tephrodes have a very characteristic "vanilla" scent which is prevalent in the "bowls" where the scattered plants grow (Figure 3). The plants exhibited an extremely strong perennial habit. The plants were also gray in color, with pubescent leaves covered with long hairs, similar to annual $H$. argophyllus T. \& G. Blanchet and Gelfi (1980) evaluated stomatal resistance, leaf water resistance, leaf water potential, photosynthetic activity, leaf structure, and number of stomata in 10 southwestern species of Helianthus. They concluded that $H$. argophyllus is the most likely source of drought resistance of the species they studied because its pubescent leaves reflect sunlight, reduce water loss, and exhibit low transpiration rates. The ability of $H$. niveus ssp. tephrodes to survive and thrive in shifting sand dunes with annual precipitation of $50 \mathrm{~mm}$ could be of value for cultivated sunflower, which is often grown in arid areas.

Characteristically, plants of $H$. niveus ssp. tephrodes have only a few flowering heads at any one time and produce only a few achenes per head. Plants flower over a several-month period. The number of achenes per head averaged only one. The low achene set could have been due to the lack of pollinators or low self-compatibility, insect/rodent predation, or the perennial habit of the species. Another possibility could have been the immaturity of the heads at the time of collection.

Helianthus niveus ssp. canescens occurs in sandy soils in desert areas (Figure 4). Blanchet and Gelfi (1980) concluded that $H$. niveus ssp. canescens was a potential species for drought tolerance. One population of $H$. niveus ssp. canescens was collected from the Yuma Marine Corps Air Station near the US-Mexico border. The area where the plants were found is more sand flats than dunes. The plants from this location were all annual and less pubescent than $H$. niveus ssp. tephrodes. Plants of $H$. niveus ssp. canescens were more erect and spreading, typical of annual plants. The plants found in this area appear to be "transitional," having characteristics of both subspecies, but having more traits characteristic of $H$. 
niveus ssp. canescens than $H$. niveus ssp. tephrodes. They have achenes which are intermediate in size between the two subspecies. They also have more flowering heads per plant than $H$. niveus ssp. tephrodes, and more heads that flower at the same time, a characteristic associated with annual plants. The number of achenes per head was also higher, with five achenes per head.

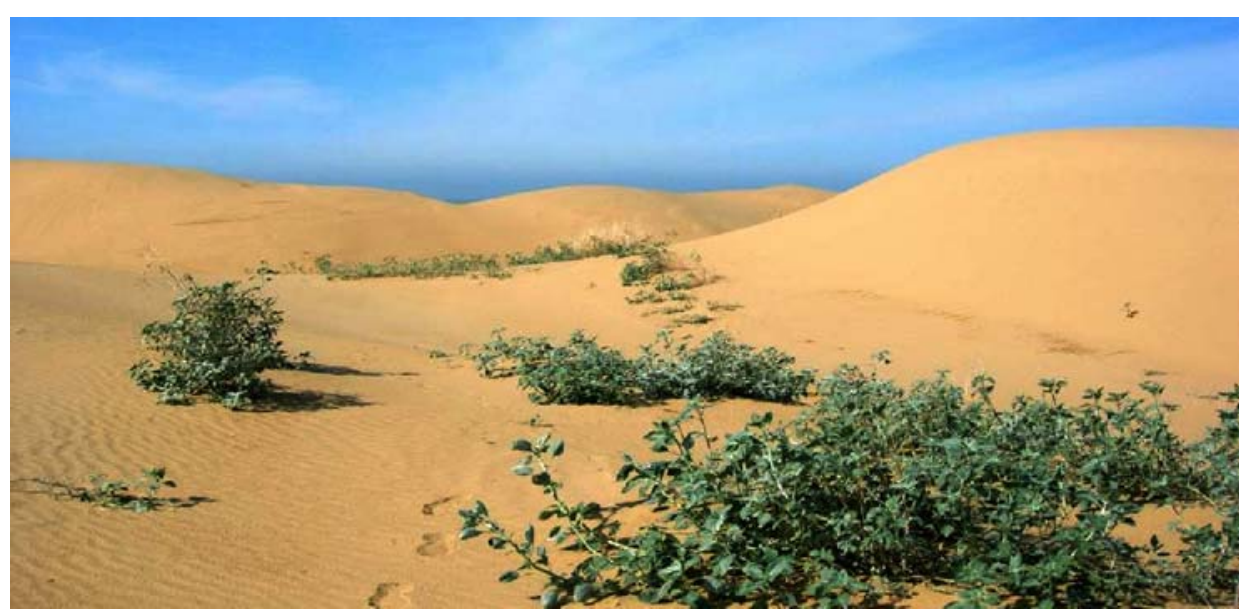

Figure 3: Typical population of H. niveus ssp. tephrodes in the Algodones Dunes, Imperial Co., California. Plants are scattered in a typical "sand bowl" usually several meters in diameter and distributed in the bottom and occasionally on the front face of the bowl.

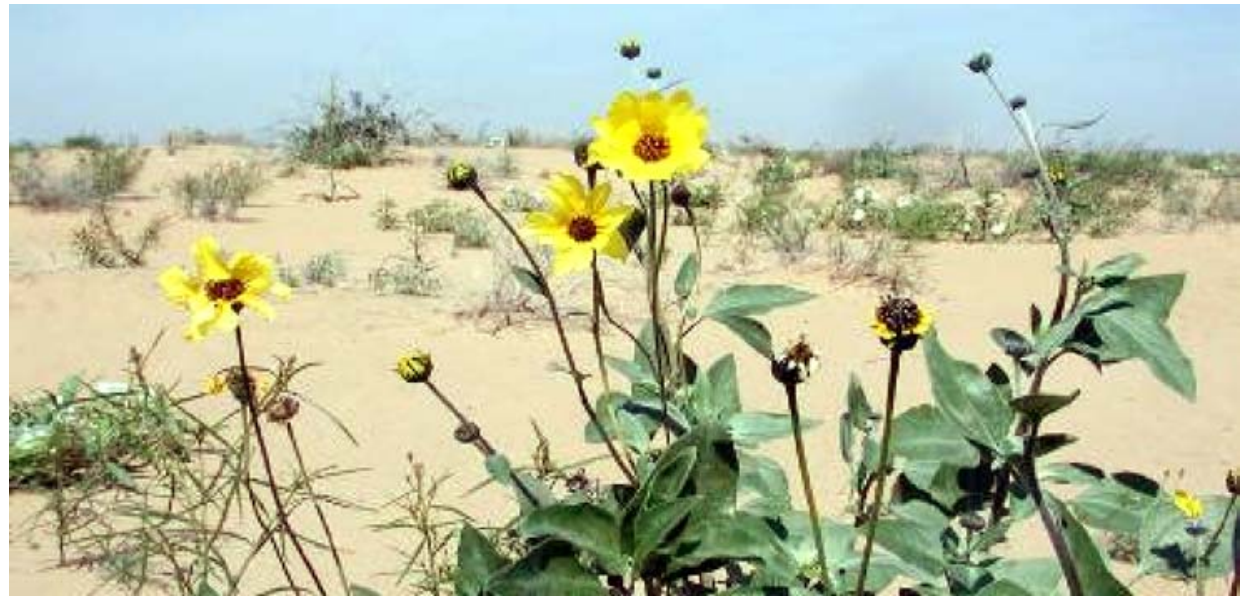

Figure 4: Annual H. niveus ssp. canescens plants in the Yuma Dunes, Yuma Co., Arizona show less pubescence and are more erect and spreading than H. niveus ssp. tephrodes.

The collection of three populations of $H$. niveus ssp. canescens from the Cabeza Prieta National Wildlife Refuge in Arizona was all within the Pinta Sands area, which is the northernmost extension of the Gran Desierto of Sonora Mexico. 
This area is characterized by mostly sandy flats with small dunes and more extensive vegetation. Plants from this area are more typical of this subspecies, with the area being on the extreme western edge of the distribution of $H$. niveus ssp. canescens. The plants are annual, very branched, with less pubescent leaves than $H$. niveus ssp. tephrodes. This subspecies has the smallest achenes of any of the annual subspecies. The number of achenes per head ranged from one to four, still low for an annual species.

The low achene set per head and the few flowering heads of H. niveus ssp. tephrodes did not allow for the adequate collection of achenes for distribution from these populations. Additional achenes need to be collected over time to obtain an adequate number of achenes, or the collected achenes need be increased in isolation cages using bees as pollinators. Future collections of H. niveus ssp. tephrodes will have to concentrate on collecting a larger number of heads and more mature achenes to reach the 2000 achene level required to allow distribution from the NPGS sunflower germplasm collection.

The somewhat better achene set in $H$. niveus ssp. canescens from the Yuma area permitted the collection of 3500 achenes per population. Two of the three populations collected from the Pinta Sands had 2200 and 3400 achenes, respectively. This will be adequate for distribution of achenes.

The achene samples have been deposited at the USDA-ARS National Plant Germplasm System, North Central Regional Plant Introduction Station, Ames, Iowa, where they are maintained and distributed. Achenes of this germplasm can be requested through the USDA-ARS NPGS GRIN system at http://www.ars-grin.gov. The limited number of desert species populations collected will provide a starting point for further research dealing with improving drought tolerance in cultivated sunflower.

\section{ACKNOWLEDGEMENT}

We thank Dean Tonenna, U.S. Department of Interior, Bureau of Land Management, Carson City, Nevada for assistance in locating populations of H. deserticola in Nevada.

\section{REFERENCES}

Blanchet, R. and Gelfi, N., 1980. Physiologie végétale caractères xérophytiques de quelques espèces d'Hélianthus susceptibles d'etre utilisés pour améliorer l'adaptation aux conditions seches du tournesol cultivé (Helianthus annuus L.). C.R. Acad. S.C. Paris T. 290. Serie D. pp. 279-282.

Bowers, J. E., 2005. El Nino and displays of spring-flowering annuals in the Mojave and Sonoran deserts. J. Torr. Bot. Soc. 132: 38-49.

Gross, B.L., Kane, N.C., Lexar, C., Ludwig, F. and Rosenthal, D.M., 2004. Reconstructing the origin of Helianthus deserticola: Survival and selection on the desert floor. Am. Nat. 164, $145-156$. 
Heiser, C.B., 1958. Three new annual sunflowers (Helianthus) from the southwestern United States. Rhodora 60: 272-283.

Heiser, C.B., Smith, D.M., Clevenger, S.B. and Martin, W.C., 1969. The North American sunflower (Helianthus). Mem. Torr. Bot. Club 22:1-218.

Ludwig, F., Rosenthal, D.M., Johnston, J.A., Kane, N., Gross, B.L., Lexar, C., Dudley, S.A., Rieseberg, L.H. and Donovan, L.A., 2004. Selection on leaf ecophysiological traits in a desert hybrid Helianthus species and early-generation hybrids. Evolution 58:2682-2692.

Nabhan, G.P. and Reichhardt, K.L., 1983. Hopi protection of Helianthus anomalus, a rare sunflower. Southw. Nat. 28:231-235.

Nevada Natural Heritage Program., 2001. Helianthus deserticola Rare Plant Data Sheet. http:/ /heritage.nv.gov/atlas/heliadeser.pdf, and http://heritage.nv.gov/atlas/heliadeser.html

Seiler, G.J., 1992. Utilization of wild sunflower species for the improvement of cultivated sunflower. Field Crops Res. 30:195-230.

Seiler, G.J. and Cuk, L., 1981. Range extension of Helianthus species (Asteraceae) in Arizona and Utah. Great Basin Nat. 41:393-394.

Thompson, T.E., Zimmerman, D.C. and Rogers, C.E., 1981. Wild Helianthus as a genetic resource. Field Crops Res. 4:333-343.

\section{RECOLECCIÓN DE LAS ESPECIAS SILVESTRES DEL GÉNERO Helianthus EN LAS PARTES DESIERTAS DEL SUROESTE DE LOS EE.UU. COMO FUENTES DE TOLERANCIA A SEgUÍA POTENCIALES}

RESUMEN

La habilidad de algunas especies de girasol de sobrevivir y crecer en dunas arenosas mviles, en las condiciones de precipitación anual de $50 \mathrm{~mm}$, podría ser útil para el girasol cultivado, plantación que a menudo se cultiva en las regiones áridas. El género Helianthus abarca 51 especies y 19 subespecies, con 14 especies anuales y 37 perennes, especies originarias de América del Norte. El objetivo de este trabajo ha sido recolectar semilla del mayor número posible de poblaciones de las especies desiertas de girasol, especialmente de las especies anuales de $H$. anomalus, $H$. deserticola, $H$. niveus ssp. canescens, y la especie perenne $H$. niveus ssp. tephrodes, de las partes desiertas de suroeste de los EE.UU., que quedarían a disposición para las futuras investigaciones y adelantamiento del girasol cultivado. La primera búsqueda de las especies $H$. anomalus y $H$. deserticola, fue publicada entre 16 y 23 de septiembre de 2000. Durante la misión se pasó $4100 \mathrm{~km}$ en tres Estados Federales, Utah, Arizona y Nevada. La segunda misión fue concentrada en las poblaciones de $H$. deserticola en la parte occidental de Nevada central y fue publicada entre 20 y 23 de junio y entre 15 y 18 de agosto de 2005. La tercera misión, en la cual se buscaba $H$. niveus ssp. tephrodes, fue publicada entre 26 de febrero y 5 de marzo de 2005. Se pasó $2200 \mathrm{~km}$ por California del Sur y las partes limítrofes de Arizona. En el año 2000, en Utah fueron recolectadas sólo una población de $H$. deserticola y dos poblaciones de $H$. anomalus. En el año 2005 en Nevada, fue recolectada semilla de 13 poblaciones de $H$. deserticola. En el año 2005, fueron recolectadas 5 poblaciones de $H$. niveus ssp. tephrodes de las dunas Algodones en California. Una población de $H$. niveus ssp. canescens fue recolectada también en Yuma, Arizona, cerca de la frontera de los EE.UU. con México. Tres poblaciones adicionales fueron recolectadas en la región de Pinta Sands en Arizona, la cual es la parte más septentrional del Gran Desierto mexicano de Sonora. Todas las muestras de semilla recolectadas, se mantienen y distribuyen de USDA-ARS, Sistema Nacional de Germoplasma Vegetal, Estación Regional de Introducción de Plantas, Ames, Iowa. El número 
limitado de poblaciones desiertas recolectadas servirá de germoplasma básica para el futuro trabajo en el mejoramiento de tolerancia a sequía en girasol cultivado.

\title{
COLLECTE D'ESPÈCES SAUVAGES D'Helianthus DANS LES RÉGIONS DÉSERTIQUES DU SUD-OUEST DES ÉTATS- UNIS EN TANT QUE SOURCES POTENTIELLES DE TOLÉRANCE À LA SÉCHERESSE
}

\author{
RÉSUMÉ
}

\begin{abstract}
L'aptitude qu'ont certaines espèces de tournesols de survivre et de se développer avec des précipitations annuelles de $50 \mathrm{~mm}$ sur des dunes de sable en mouvement pourrait être d'utilité pour le tournesol de culture, plante souvent cultivée dans les régions arides. Le genre Helianthus est composé de 51 espèces et de 19 sous-espèces, avec 14 espèces annuelles et 37 espèces vivaces qui sont toutes d'origine nord-américaine. Le but de cette recherche était de recueillir les akènes du plus grand nombre possible de populations d'espèces des déserts, et en particulier des espèces annuelles $H$. anomalus, $H$. deserticola, $H$. niveus ssp. canescens ainsi que de l'espèce vivace $H$. niveus ssp. tephrodes des régions désertiques du sud-ouest des États-Unis et de les mettre à la disposition de recherches futures pour qu'elles puissent servir au développement de la culture du tournesol. Les premiers travaux de recherche des espèces $H$. anomalus et $H$. deserticola ont été faites du 16 au 23 septembre 2000 sur $4100 \mathrm{~km}$ dans trois états fédéraux, l'Utah, l'Arizona et le Nevada. La deuxième mission portait sur la population $H$. deserticola et elle a été menée du 20 au 23 juin et du 15 au 18 août 2005 dans la partie occidentale du Nevada central tandis que la troisième qui portait sur le $H$. niveus ssp. tephrodes a été effectuée du 26 février au 5 mars 2005. Un territoire de $2200 \mathrm{~km}$ en Californie du Sud et dans les régions voisines de l'Arizona a été couvert. Une seule population de $H$. deserticola et deux populations de $H$. anomalus ont été recueillies en Utah en 2000. Au Nevada, les akènes de 13 populations de $H$. deserticola ont été recueillis en 2005. Cinq populations de $H$. niveus ssp. tephrodes ont été ramassées dans les dunes Alogodones en Californie en 2005. Une population de $H$. niveus ssp. canescens provient de Yuma, Arizona, près de la frontière américano-mexicaine. Trois populations supplémentaires ont été ramassées en Arizona, dans la région de Pinta Sands qui est la partie la plus septentrionale du Grand Désert Sonora du Mexique. Tous les échantillons d'akènes recueillis sont gardés et distribués par le système national de germoplasme USDA-ARS, centre régional, Ames, Iowa. Le nombre limité de populations d'espèces des déserts servira de base de germoplasme pour un travail futur sur l'amélioration de la tolérance à la sécheresse chez le tournesol cultivé
\end{abstract}

Presented at:

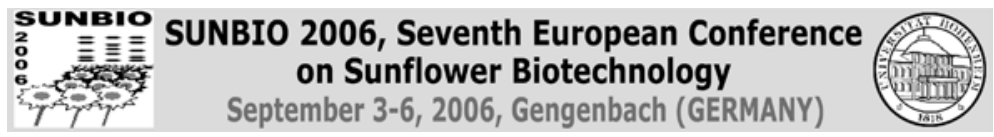


